\title{
Strategi Promosi dalam Pengembangan Pariwisata Lokal di Desa Wisata Jelekong
}

\author{
Nisa Amalina Setiawan \\ Fakultas Komunikasi dan Bisnis \\ Universitas Telkom \\ Jl. Telekomunikasi, Ters. Buah Batu Dayeuhkolot Bandung 40257 \\ E-Mail:nisa.amalina@yahoo.com \\ Farid Hamid U. \\ Fakultas Komunikasi dan Bisnis \\ Universitas Telkom \\ J1. Telekomunikasi, Ters. Buah Batu Dayeuhkolot Bandung 40257
}

\begin{abstract}
The approach of this research is qualitative, using case study method. The data was obtained through in-depth interview, observation, literature study, and documentation. The data analysis steps used were data reduction, data display, and verification. The purpose of the research is to investigate the promotion strategy of the tourism village of Jelekong, Bandung Regency performed by Kompepar Giriharja. The result of the research shows that Kompepar Giriharja performs promotion mix, i.e., word of mouth, public relations, personal selling, event, exhibition, merchandise, publication, and website. From overall promotion strategy applied by Kompepar Giriharja, the main priority was through event and public relations. The conclusion of this research is Kompepar Giriharja has not formulated comprehensive and integrated promotion strategy.
\end{abstract}

Keywords: promotion strategy, tourism village, promotion mix.

\begin{abstract}
ABSTRAK
Penelitian ini dilakukan dengan menggunakan pendekatan kualitatif melalui metode studi kasus. Data diperoleh melalui wawancara mendalam, observasi, studi literatur, dan dokumentasi. Adapun langkah-langkah analisis data meliputi reduksi data, penyajian data, dan verifikasi. Tujuan pelaksanaan penelitian ini adalah untuk mengetahui strategi promosi desa wisata Jelekong, Kabupaten Bandung yang dijalankan oleh Kelompok Penggerak Pariwisata (Kompepar) Giriharja. Berdasarkan hasil penelitian yang diperoleh, Kompepar Giriharja menjalankan promotion mix yang meliputi word of mouth, public relations, personal selling, event, eksibisi, merchandise, publikasi, dan website internet. Dari keseluruhan bentuk promosi, prioritas utama promosi dilakukan melalui event dan public relations. Dalam penelitian ini disimpulkan bahwa Kompepar Giriharja belum merumuskan strategi promosi secara komprehensif dan terintegrasi.
\end{abstract}

Kata Kunci: strategi promosi, desa wisata, promotion mix. 


\section{PENDAHULUAN}

Komunikasi merupakan salah satu aspek penting dalam pemasaran sektor pariwisata suatu daerah. Menurut Soemanagara (2008:2), pentingnya pemahaman tentang komunikasi ini ditujukan agar informasi yang disampaikan dapat memberikan dampak yang diinginkan dan mencapai sebuah kesamaan kehendak. Aplikasi komunikasi dalam pemasaran disebut komunikasi pemasaran. Soemanagara (2008:63) menyebutkan, komunikasi pemasaran bertujuan untuk mencapai tiga tahap perubahan yang ditujukan kepada konsumen, antara lain perubahan knowledge (pengetahuan), perubahan sikap, dan perubahan perilaku.

Jawa Barat merupakan salah satu provinsi dengan potensi pariwisata yang besar. Pentingnya aspek promosi wisata disadari betul oleh pemerintah provinsi Jawa Barat. Hal tersebut terwujud melalui pembentukan Badan Promosi Pariwisata Jawa Barat yang telah menggelar serangkaian promosi dan expo dengan menghadirkan peserta para pelaku pariwisata dari dalam dan luar negeri (www.bapedajabar.go.id/index.php/subMenu/informasi/berita/ detailberita/79).

Upaya dari pemerintah Provinsi Jawa Barat dalam mengembangan sektor pariwisata tersebut memang beralasan. Pariwisata memiliki potensi besar untuk menjadi salah satu pilar dalam membangun perekonomian nasional. Seperti yang dikemukakan Lubis dan Osman (2014), pariwisata mampu menghasilkan pertumbuhan ekonomi di Indonesia dan negara-negara di Asia Tenggara serta di Asia pada umumnya. Sektor pariwisata dapat menciptakan peluang usaha, membuka lapangan pekerjaan, memperbaiki tingkat pendapatan, dan mendorong pemerataan pendapatan penduduk serta dapat meningkatan pendapatan negara dari sektor pajak. Sektor pariwisata dapat menstimulus berbagai sektor produksi, serta memberikan kontribusi secara langsung bagi kemajuan-kemajuan dalam usahausaha pembuatan dan perbaikan pelabuhan, jalan raya, pengangkutan, serta mendorong pelaksanaan program kebersihan dan kesehatan, proyek sarana budaya, pelestarian lingkungan hidup dan sebagainya yang dapat memberikan keuntungan dan kesenangan baik kepada masyarakat setempat maupun wisatawan dari luar (Subagyo, 2012). Sejalan dengan pendapat
Pendit, Djayawangi (2013) menyampaikan kontribusi yang disumbangkan sektor pariwisata di Jawa Barat dapat dilihat dari nilai kontribusi positif berupa keuntungan-keuntungan baik bagi pemerintah, pelaku pariwisata maupun masyarakat

Perkembangan pariwisata yang cukup pesat di Indonesia umumnya serta di Provonsi Jawa Barat khususnya telah membawa banyak perubahan terutama dalam konsep dan tujuan berwisata. Wisatawan tidak lagi hanya cukup menikmati keindahaan alam tempat wisata dengan segala fasilitas wisatanya. Sekarang ini banyak wisatawan yang juga ingin menikmati keleluasaan berwisata dengan cara berinteraksi langsung dengan lingkungan dan masyarakat lokal. Perubahan inilah yang mendorong muculnya konsep pariwisata pedesaan yang ditandai dengan munculnya desa-desa wisata di berbagai provinsi di Indonesia (Suyanti, 2013).

Desa wisata didefinisikan secara beragam. Salah satu pemahaman tentang wisata desa yang dikemukakan oleh Suyanti (2013) adalah suatu bentuk lingkungan yang memiliki ciri khusus, baik alam maupun budaya yang sesuai dengan tuntutan wisatawan, di mana mereka dapat menikmati mengenal, menghayati dan mempelajari kekhasan desa beserta segala daya tariknya.

Di Provinsi Jawa Barat, dari sekian banyak potensi wisata, salah satunya adalah wisata desa yang cukup potensial yaitu yang berada desa Jelekong. Jelekong merupakan nama sebuah kelurahan yang terletak di kecamatan Baleendah, Kabupaten Bandung, Jawa Barat. Desa Jelekong menyuguhkan beragam objek wisata, antara lain panorama khas pedesaan, objek wisata alam, juga sentra pembuatan kerajinan wayang golek, pertunjukan seni Sunda, kerajinan tangan, hingga penghasil lukisan yang potensial. Melalui SK Bupati Bandung Nomor 556.42/ Kep.71-Dispopar/2011， Pemerintah Kabupaten Bandung menetapkan Jelekong sebagai satu dari sepuluh desa wisata di Kabupaten Bandung (www. bandungkab.go.id/arsip/557/ditetapkan-10-desawisata). Penetapan Jelekong sebagai desa wisata ini telah dipublikasikan pada situs resmi pemerintah Kabupaten Bandung.

Jelekong ditetapkan sebagai desa wisata dengan jenis wisata seni budaya serta produk unggulan yang terdiri atas handycraft, seni budaya, pertanian, perkebunan, seni lukis, dan kuliner tradisional. 
Beragam potensi wisata desa Jelekong memang tidak perlu diragukan lagi. Di antara sepuluh desa wisata yang ditetapkan bupati Bandung, Jelekong merupakan desa/kelurahan yang menjadi ikon wisata di Kabupaten Bandung (wawancara pra penelitian dengan Dede Saepulrohim, pelaku seni Jelekong pada Rabu, 13 November 2013). Jelekong memiliki beragam produk unggulan yang lengkap, mulai dari wayang golek, seni mendalang, seni lukis, kuliner tradisional seperti awug, hasil pertanian dan perkebunan seperti buah sawo walanda, serta berbagai kesenian khas sunda lainnya.

Hingga tahun 2013, sekitar 700-800 orang penduduk Jelekong merupakan pengrajin lukisan, dengan 400 orang di antaranya adalah pelukis aktif (wawancara pra penelitian dengan Asep Sancang, Rabu, 13 November 2013). Para pelukis ini belajar melukis secara otodidak atau berguru pada pelukis senior di Jelekong. Hanya beberapa orang saja yang mengikuti pendidikan formal seni atau desain di perguruan tinggi. Lukisan karya penduduk Jelekong dapat dengan mudah ditemui di sepanjang jalan di kampung Jelekong. Di samping dapat melihat berbagai lukisan di galeri yang tersebar di kampung ini, para pengunjung juga dapat menyaksikan proses pembuatan lukisan. Karena itu, kampung ini terbilang unik dan dapat menjadi destinasi wisata yang menarik bagi para pengunjung. Di Eropa konsep menggagas desa wisata dengan tematema tertentu dimulai oleh beberapa negara yang ada di Eropa bagian barat seperti Austria, Perancis, Belanda, dan Itali. Negara-negara tersebut telah sukses dalam mengembangkan desa wisata dengan tema khusus dan berhasil menarik wisatawan asing untuk berkunjung (Dombrowicz, 2013).

Sementara itu, seni pedalangan wayang golek desa Jelekong dirintis dan dikembangkan oleh abah Sunarya dan generasi penerusnya, seperti Asep Sunandar Sunarya, Ade Sunarya, dan seterusnya. Hingga didirikanlah padepokan wayang golek oleh abah Sunarya di desa Jelekong. Wisatawan yang berkunjung khususnya rombongan dalam jumlah besar dapat menikmati paket wisata berupa mengikuti proses pengerjaan kerajinan wayang golek dan menyaksikan pertunjukan wayang golek. Seni wayang golek semakin mengokohkan budaya Indonesia setelah wayang ditetapkan oleh UNESCO sebagai salah satu Intangible Cultural Heritage of Humanity (warisan budaya tak berwujud) pada tahun 2003 lalu (http://www.unesco.org/culture/ich/RL/00063).
Potensi seni dan budaya di Jelekong ini menyebar di beberapa lokasi. Namun pusatnya ada di kawasan RW 01 kelurahan Jelekong yang lebih dikenal dengan nama Giriharja (observasi pra penelitian). Begitu pula dengan padepokan wayang golek abah Sunarya yang berlokasi di kawasan ini, sehingga tidak sedikit masyarakat yang lebih mengenal nama Giriharja dibanding Jelekong. Penetapan Jelekong sebagai satu dari sepuluh desa wisata yang ada di desa Jelekong dilakukan pada tahun 2011. Sementara itu sebelumnya, tepatnya pada tahun 2010, Kelompok Penggerak Pariwisata (Kompepar) Kab. Bandung menetapkan Kompepar unit kecamatan, salah satunya Kompepar Giriharja melalui SK Kompepar Kabupaten Bandung Nomor 03/SKKompepar Kab./K.3/XII/2010. Kelompok Penggerak Pariwisata (Kompepar) merupakan sebuah kelompok masyarakat yang berperan dalam pengembangan dan pengelolaan potensi suatu desa wisata. Kompepar unit memiliki tugas utama melakukan perencanaan dan melaksanakan fungsi penggerak pariwisata di tingkat unit daya Tarik Wisata (DTW)/Objek Daerah Tujuan Wisata (ODTW) yang meliputi promosi, sosialisasi, sosial dan pencitraan seni budaya dan kepariwisataan di wilayahnya.

Umumnya, setiap desa wisata hanya memiliki satu Kompepar. Namun berbeda dengan Kelurahan Jelekong yang memiliki dua Kompepar sekaligus. Kompepar yang ada di desa wisata Jelekong, antara lain Kompepar Giriharja dan Kompepar Gentong. Kompepar ini terdiri atas perwakilan penduduk setempat yang memiliki gagasan serta membuat susunan program dalam mengembangkan pariwisata desa Jelekong. Pada penelitian ini, peneliti hanya membahas Kompepar Giriharja saja yang mengusung produk unggulannya, yakni wayang golek dan lukisan Jelekong.

Sebagaimana salah satu fungsinya yakni merencanakan dan melaksanakan promosi, pihak Kompepar Giriharja harus memperhatikan aspek komunikasi yang tepat agar informasi mengenai desa Jelekong ini dapat sampai ke masyarakat hingga akhirnya menarik pengunjung untuk datang. Seperti objek wisata lainnya, desa wisata Jelekong membutuhkan suatu strategi komunikasi pemasaran yang terumuskan secara komprehensif agar pesan dan informasi mengenai desa wisata ini dapat sampai pada target pengunjung secara efektif dan efisien. 
Penerapan komunikasi pemasaran desa wisata Jelekong oleh Kompepar Giriharja ini dapat dilakukan melalui aktivitas promosi. Seperti yang telah dijelaskan sebelumnya, aktivitas komunikasi pemasaran dalam bentuk promosi merupakan aspek yang penting, sehingga seberapapun uniknya potensi wisata di Jelekong, tidak akan dikenal masyarakat apabila tidak dipromosikan dengan tepat dan maksimal. Strategi promosi ini juga penting dilakukan, karena sektor pariwisata saat ini merupakan industri yang kompetitif. Dalam industri pariwisata yang berkembang pesat, persaingan menjadi semakin tinggi, sehingga strategi promosi destinasi wisata semakin penting peranannya (Chandra dan Menezes, 2001). Rehman dan Ibrahim (2011) menyebutkan bahwa program komunikasi pemasaran sangat erat dan berhubungan dengan adanya perubahan pola konsumsi, teknik promosi, dan persaingan usaha.

Penelitian ini bertujuan untuk mengetahui bagaimana strategi promosi desa wisata Jelekong, Kabupaten Bandung yang dijalankan oleh Kelompok Penggerak Pariwisata (Kompepar) Giriharja.

\section{METODE}

\section{Metode Penelitian}

Penelitian ini menggunakan metode kualitatif. Pendekatan yang digunakan dalam penelitian ini adalah studi kasus. Metode studi kasus bertujuan untuk memberikan gambaran secara mendetail tentang latar belakang, sifat-sifat, dan karakter-karakter yang khas dari kasus ataupun status individu, yang kemudian, dari sifat-sifat khas akan dijadikan sebagai suatu hal yang bersifat umum (Prastowo, 2011:130).

\section{Informan}

Peneliti mewawancarai beberapa informan yang dianggap relevan dan dapat memberikan data yang dibutuhkan. Dalam penelitian ini, informan terbagi menjadi dua, yakni informan kunci (key informan) dan informan pendukung. Informan kunci dalam penelitian ini antara lain Bapak Irwansyah, selaku ketua Kompepar Giriharja dan Bapak Nandang Sudrajat, selaku sekretaris Kompepar Giriharja. Sementara itu, terdapat informan pendukung dalam penelitian ini. Pertama, yaitu Bapak Idas Koswara, selaku salah satu pengurus Kompepar Kabupaten Bandung. Dua informan pendukung lain merupakan pelaku seni Jelekong, yakni Bapak Dede Saepulrohim dan Bapak Asep Sancang.

\section{Sumber Data}

Berdasarkan sumber datanya, pengumpulan data dapat menggunakan sumber primer dan sumber sekunder. Teknik pengumpulan data primer pada penelitian ini dilakukan melalui wawancara mendalam dan observasi. Sementara itu, data sekunder penelitian ini diperoleh melalui studi literatur dan dokumentasi.

\section{Teknik Analisis Data}

Teknik analisis data menggunakan model proses analisis data Miles dan Huberman yang terdiri atas tiga tahapan (Sugiyono, 2010:91). Pertama, reduksi data, yaitu merangkum dan memilih data yang bersifat penting dan pokok lalu membuat kategori. Kedua, penyajian data (data display), yakni penyajian data dalam bentuk yang lebih tersusun dan berpola. Terakhir, verifikasi atau penarikan kesimpulan.

\section{HASIL}

\section{Identifikasi Lembaga Pelaksana Promosi}

Terdapat dua lembaga pelaksana promosi desa wisata Jelekong, yakni Kelompok Penggerak Pariwisata (Kompepar) Gentong dan Kompepar Giriharja. Pada penelitian ini, peneliti hanya meneliti strategi promosi desa wisata Jelekong yang dilakukan oleh Kompepar Giriharja. Kompepar Giriharja dibentuk berdasarkan Surat Keputusan (SK) Kompepar Kab. Bandung Nomor 03/SK-Kompepar. Kab./K.3/XII/2010 pada 29 Desember 2010.

\section{Elemen Strategi Promosi Desa Wisata Jelekong}

Elemen strategi promosi desa wisata Jelekong terbagi menjadi delapan, antara lain bauran promosi (promotion mix), target pengunjung, tujuan promosi, anggaran promosi, rancangan pesan, media yang digunakan, sumber pesan, dan umpan balik (feedback).

Dalam pelaksanaannya di lapangan, pengurus Kompepar Giriharja belum memiliki susunan program promosi desa wisata Jelekong secara terintegrasi dan intensif. Elemen promotion mix yang digunakan Kompepar Giriharja, di antaranya eksibisi (pameran), personal selling, event, public relations, sales promotion (merchandise), website, publikasi melalui televisi, dan promosi melalui mulut ke mulut (word of mouth).

Tujuan kunjungan ke desa wisata Jelekong bermacam-macam, mulai dari wisata belanja, keperluan studi/penelitian, studi banding, hingga belajar gamelan. Apabila diidentifikasi berdasarkan 
pengunjung yang datang hingga saat ini, audiens sasaran desa wisata Jelekong, antara lain pelajar dan mahasiswa, tamu pemerintahan dan kenegaraan, instansi/perusahaan, media, dan umum.

Sementara itu, berdasarkan hasil wawancara dengan ketua Kompepar Giriharja, penulis dapat menyimpulkan bahwa promosi desa wisata Jelekong belum dikelola secara optimal. Sehingga pengurus Kompepar Giriharja belum menetapkan tujuan berkelanjutan terkait aktivitas promosi desa wisata Jelekong. Namun meskipun begitu, melalui berbagai bentuk promotion mix yang dilaksanakan, mengindikasikan Kompepar Giriharja menargetkan terjadinya tahap perubahan pada target pengunjung. Tujuan promosi desa wisata Jelekong, di antaranya membangun awareness, memberitahu (informatif), dan mengingatkan (remembering).

Promosi desa wisata memanfaatkan berbagai sumber anggaran. Beberapa sumber anggaran diperoleh melalui kerjasama dengan pihak pemerintah kabupaten, pemerintah provinsi, maupun kerjasama dengan pihak swasta. Berbagai dana bantuan, baik dari pemerintah maupun swasta umumnya masih diprioritaskan untuk pemenuhan sarana prasarana.

Aktivitas promosi yang belum tersusun menjadi program kerja Kompepar Giriharja menyebabkan aspek rancangan pesan belum terlalu diperhatikan. Isi pesan promosi umumnya masih berupa penyampaian informasi mengenai desa wisata Giriharja, Jelekong. Itu pun dalam jumlah yang terbatas sehingga masyarakat harus mencari tahu dan mengumpulkan sendiri informasi mengenai desa wisata Jelekong. Selain itu, isi pesan yang disampaikan umumnya berupa ide moral, yaitu pengembangan dan pelestarian seni budaya yang memuat nilai-nilai kearifan lokal.

Media penyampaian pesan promosi desa wisata Jelekong terbagi menjadi dua, yakni saluran komunikasi tidak bermedia dan saluran komunikasi melalui media perantara. Saluran komunikasi tidak bermedia meliputi komunikasi tatap muka dan word of mouth (WOM). Saluran penyampaian pesan melalui media dilakukan menggunakan televisi, surat kabar, dan internet. Di samping itu, ikon Jelekong, yakni wayang golek dan lukisan seringkali digunakan sebagai media penyampaian pesan.

Jelekong memiliki tokoh pedalangan yang dikenal luas di masyarakat, yakni keluarga Sunarya atau disebut juga dengan dinasti Sunarya. Karena itulah, hal ini dimanfaatkan dengan baik oleh pengurus Kompepar Giriharja. Selain promosi yang dilakukan langsung oleh para pengurus Kompepar Giriharja sendiri, aktivitas penyampaian informasi desa Jelekong pun dilakukan secara tidak langsung oleh para kelompok seni budaya Giriharja ini.

Umpan balik yang diperoleh Kompepar Giriharja berasal dari audiens sasaran atas aktivitas promosi, yakni calon pengunjung, serta para pelaku seni setempat. Aktivitas promosi tertentu cukup membuat jumlah kunjungan meningkat. Sementara itu, umpan balik dari pelaku seni Jelekong, terdapat sebagian orang pengrajin, khususnya pengrajin lukisan yang masih cenderung negatif dan kurang antusias dengan pembinaan yang dilakukan oleh Kompepar Giriharja. Namun tak sedikit pula jumlah pengrajin yang antusias dalam mengikuti berbagai program pembinaan yang dijembatani oleh Kompepar Giriharja.

Disamping menjelaskan lembaga pelaksana promosi dan elemen strategi desa wisata Jelekong, penulis juga menyajikan penjelasan singkat mengenai hambatan yang dihadapi Kompepar Giriharja dalam menjalankan strategi promosi desa wisata Jelekong. Hambatan ini terbagi menjadi dua, yakni hambatan teknis dan hambatan non teknis. Hambatan teknis berkaitan dengan minimnya pengetahuan promosi para pengurus dan perbedaan bahasa. Hambatan non teknis yang dihadapi, antara lain terbatasnya anggaran dana promosi, kurangnya SDM, belum siapnya sarana prasarana, dan kurangnya dukungan pelaku seni.

Berdasarkan hasil penemuan di lapangan yang dipaparkan tersebut, promosi desa wisata Jelekong oleh Kompepar Giriharja dapat digambarkan pada Gambar 1.

\section{PEMBAHASAN}

Di dalam aktivitas promosi yang dilakukan Kompepar Giriharja, terjadi proses komunikasi. Pada aktivitas promosi desa wisata Jelekong tersebut melibatkan unsur-unsur komunikasi, yaitu pertama adalah unsur komunikator, yang bertindak sebagai komunikator, dalam promosi desa Jelekong bertindak sebagai komunikator adalah Kompepar Giriharja. Kompepar Giriharja pada akhirnya menjadi komunikan saat memperoleh respon atas pesan promosi. Pesan sebagai unsur komunikasi yang kedua berisi materi promosi desa wisata Jelekong dengan ikonnya, yakni seni dan budaya. Pesan promosi ini disampaikan oleh pengurus Kompepar Giriharja yang bertindak sebagai lembaga pelaksana promosi ataupun sumber pesan lain, seperti tokoh pedalangan di Jelekong. 


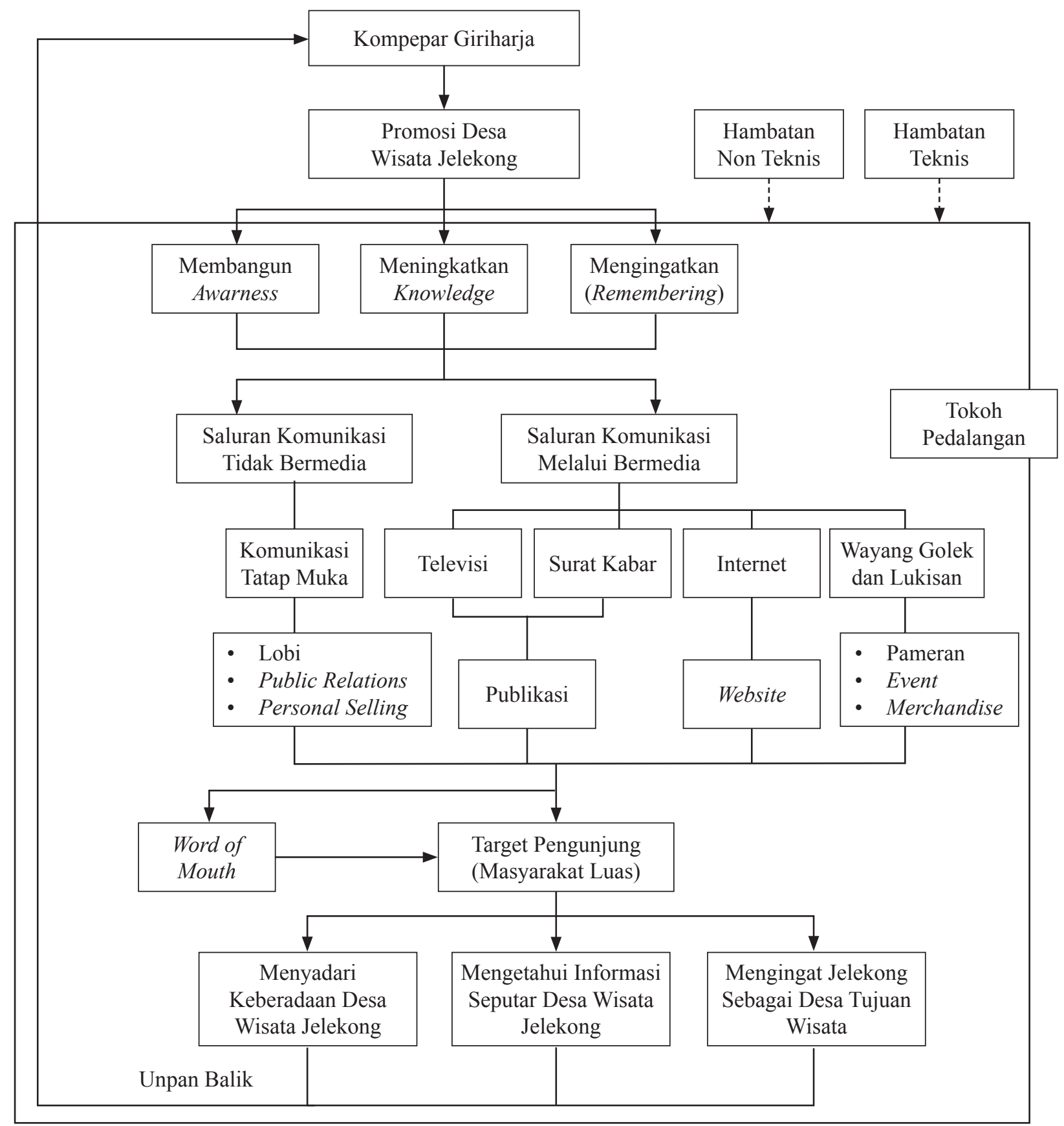

Gambar 1. Resume Strategi Promosi

Desa Jelekong oleh Kompepar Giriharja

Selanjutnya media sebagai unsur yang ketiga yang digunakan dalam penyampaian pesan promosi meliputi saluran komunikasi tidak bermedia, seperti komunikasi tatap muka dan word of mouth. Serta saluran komunikasi melalui media yang meliputi televisi, surat kabar, dan internet. Serta media yang merupakan ikon desa jelekong, yakni wayang golek dan lukisan. Hubungan antar personal dan word of mouth merupakan sumber informasi utama pada saat konsumen akan membuat keputusan. Pengaruh informasi antar personal dan WOM ini sangat penting terutama dalam sektor jasa pariwisata yang sangat dipengaruhi oleh faktor keramah tamahan (litvin et al., 2008). Dengan perkembangan teknologi komunikasi, 
khususnya perkembangan teknologi sebagai media sosial, WOM digital menjadi sumber informasi berskala besar, dengan cakupan skala internasional. Dengan demikian ke depannya WOM digital akan menjadi menjadi faktor penting dalam promosi jasa pariwisata.

Penerima pesan promosi desa wisata Jelekong adalah masyarakat luas. Namun pada akhirnya, masyarakat luas akan berperan sebagai komunikator pada proses penyampaian umpan balik atas pesan promosi dari Kompepar Giriharja. Umpan balik yang berasal dari penerima pesan (masyarakat luas) akibat penyampaian pesan promosi desa wisata Jelekong. Umpan balik ini ditujukan kepada pengurus Kompepar Giriharja. Hambatan yang terjadi dapat berasal dari teknis, dan non teknis. Hambatan teknis berupa minimnya pengetahuan promosi para pengurus Kompepar Giriharja dan perbedaan bahasa yang tidak jarang dihadapi pengurus Kompepar Giriharja dengan wisatawan asing. Dengan kata lain diperlukan berbagai pelatihan ataupun program pendampingan untuk pengelola Kompepar Giriharja untuk lebih meningkatkan kemampuannya dalam mengelola desa wisata. Hal ini sejalan dengan pendapat Sung dan kawan-kawan (2012) menyebutkan untuk pengembangan desa wisata di Sabah Malaysia dalam jangka panjang disarankan dilakukan program pendampingan untuk meningkatkan kemampuan para pengelola wisata dalam aspek kepariwisataaan dan teknologi pendukung.

Sementara itu, hambatan non teknis yang dialami, antara lain terbatasnya dana anggaran promosi, kurangnya SDM pelaksana promosi, belum siapnya sarana prasarana, dan dukungan dari pelaku seni. Di dalam penelitian yang dilakukan oleh Mahmoudi et al. (2011) menyebutkan bahawa salah satu strategi yang harus dilakukan dalam rangka mengembangankan desa wisata adalah pembangunan sarana prasarana infrastruktur wisata dan perencanaan sektor pariwisata. Pentingnya peningkatan fasilitas dan infrastruktur yang menunjang sektor pariwisata di Bali dikemukakan oleh Dharmawan et al. (2014) yang melakukan studi tentang Strategi Pengembangan Desa Wisata Di Desa Belimbing Kecamatan Pupuan Kabupaten Tabanan.

Pada aktivitas promosi Kompepar Giriharja, terjadi proses komunikasi. Berikut gambaran model komunikasi pada aktivitas promosi desa Jelekong oleh Kompepar Giriharja.

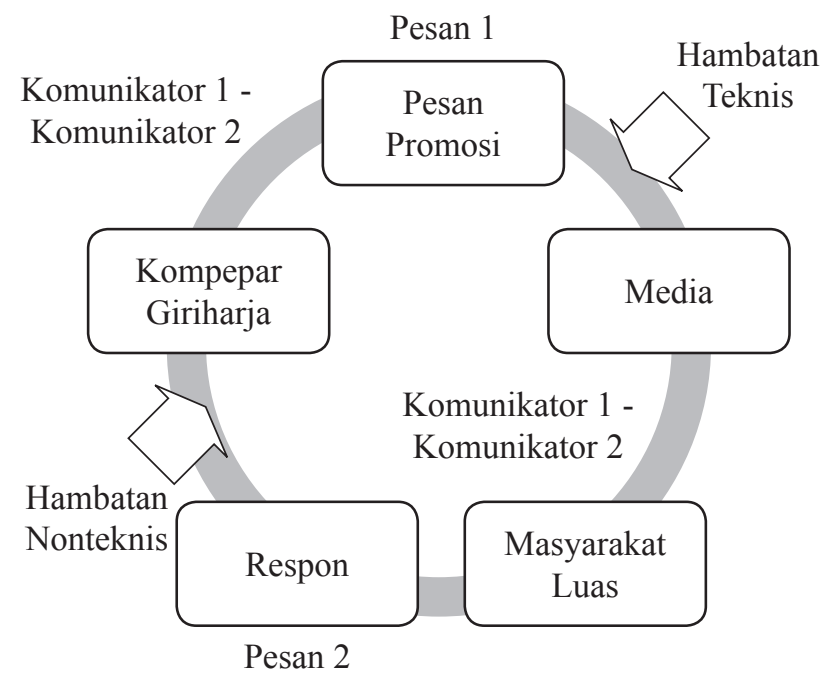

Gambar 2. Model komunikasi pada promosi Desa Jelekong oleh Kompepar Giriharja

Menurut Rangkuti (2009:51), promosi adalah salah satu dari variabel marketing mix yang sangat penting peranannya, sehingga merupakan suatu kegiatan yang harus dilakukan oleh perusahaan dalam rangka melaksanakan program promosi bila produknya ingin dikenal oleh konsumen secara luas dan sukses di pasar sasaran.

Sebagaimana pendapat Rangkuti, promosi memang penting peranannya untuk mengkomunikasikan suatu objek wisata agar dikenal masyarakat dan akhirnya menarik wisatawan untuk berkunjung. Penetapan Kompepar menunjukkan keseriusan pemerintah daerah dalam mengelola pariwisata. Karena tugas Kompepar ialah melakukan perencanaan dan melaksanakan fungsi penggerak pariwisata di tingkat unit daya Tarik Wisata (DTW)/ Objek Daerah Tujuan Wisata (ODTW) yang meliputi promosi, sosialisasi, sosial dan pencitraan seni budaya dan kepariwisataan di wilayahnya. (SK Kompepar Kab. Bandung Nomor 03/SK-Kompepar.Kab./K.3/ XII/2010). Termasuk diantaranya kelurahan Jelekong, Kecamatan Baleendah, Kabupaten Bandung yang telah ditetapkan menjadi satu dari sepuluh desa wisata yang ada di Kabupaten Bandung.

Berdasarkan hasil penelitian yang diperoleh, penulis menemukan bahwa tidak seperti desa wisata lainnya yang hanya memiliki satu Kompepar yang bertugas melakukan fungsi promosi wisata. Desa wisata Jelekong memiliki dua Kompepar, yakni Kompepar Giriharja dan Kompepar Gentong dengan 
produk unggulannya yang berbeda. Namun, kedua Kompepar ini sama-sama bertindak sebagai lembaga pelaksana promosi desa wisata Jelekong. Dualisme kepengurusan Kompepar ini pun tidak mengganggu pengembangan potensi wisata di Jelekong. Justru dengan adanya dua Kompepar ini seperti terjadi pembagian fokus pengelolaan potensi wisata. Sebagaimana yang dikatakan Idas Koswara, selaku sekretaris Kompepar Kab. Bandung, bahwa adanya dua Kompepar ini disebabkan Kompepar Giriharja yang fokus pada pengembangan seni budaya, sedangkan Kompepar Gentong yang fokus pada pengembangan objek wisata alamnya.

Penelitian ini hanya berfokus pada strategi promosi yang dilakukan oleh Kompepar Giriharja. Lebih lanjut, penelitian ini menyimpulkan bahwa Kompepar Giriharja belum menyusun strategi promosi secara terorganisir dan intensif. Untuk mencapai strategi promosi efektif, terdapat beberapa hal yang perlu diperhatikan, antara lain promotion mix, audiens sasaran, tujuan promosi, anggaran promosi, rancangan pesan, media yang digunakan, sumber pesan, dan umpan balik (feedback), dan mengintegrasikan bauran promosi. Berdasarkan praktiknya di lapangan, Kompepar Giriharja hanya menjalankan hampir seluruh elemen tersebut.

Aspek pertama yang akan dibahas ialah tujuan promosi. Berdasarkan hasil penelitian yang diperoleh, tujuan utama komunikasi dalam aktivitas promosi yang dilakukan Kompepar Giriharja masih difokuskan pada tahap pertama, yakni perubahan pengetahuan. Hal ini dikarenakan dengan belum siapnya objek wisata beserta sarana prasarana penunjang di Jelekong. Meskipun begitu, Kompepar Giriharja pun telah menyiapkan program promosi dengan tujuan komunikasi selanjutnya, yaitu perubahan sikap maupun perubahan perilaku. Hal ini sejalan dengan beberapa pendapat dari Mihart (2012) dan Rehman (2011) yang menyebutkan bahwa komunikasi pemasaran akan berdampak pada perilaku konsumen, dan bagaimana proses pengambilan keputusan konsumen tersebut.

Tujuan promosi berhubungan dengan respon yang diharapkan atas pelaksanaan aktivitas promosi. Tujuan promosi yang dilakukan oleh Kompepar, antara lain pembentukan awareness mengenai keberadaan desa wisata Jelekong serta Kompepar Giriharja, peningkatan pengetahuan (knowledge) masyarakat mengenai desa Jelekong beserta potensi wisata yang disuguhkannya, dan mengingatkan masyarakat mengenai Jelekong sebagai salah satu destinasi wisata di Kabupaten Bandung.

Pada bagian ini, peneliti berusaha menganalisis apakah elemen promotion mix dan media yang digunakan telah sesuai dengan tujuan promosi yang hendak dicapai. Berdasarkan hasil penelitian yang diperoleh, Kompepar Giriharja menggunakan beberapa bentuk promotion mix. Tabel 1. menunjukkan beberapa bentuk promotion mix desa wisata Jelekong beserta media yang digunakannya.

Media yang digunakan terdiri atas dua saluran, yakni saluran komunikasi tidak bermedia dan saluran komunikasi melalui media. Dari kedua saluran ini, akan bermuara pada berbagai bentuk promosi yang dilaksanakan desa wisata Jelekong. Seperti yang dijelaskan Kotler dan Armstrong (2008: 116), bauran promosi (promotion mix) - juga disebut bauran komunikasi pemasaran (marketing communication mix) perusahaan merupakan panduan spesifik iklan, promosi penjualan, hubungan masyarakat, penjualan personal, dan sarana pemasaran langsung yang digunakan perusahaan untuk mengomunikasikan nilai pelanggan secara persuasif dan membangun hubungan pelanggan. Beberapa aspek penting dalam komunikasi pemasaran yang terintegrasi adalah pengetahuan konsumen, data yang mendukung pengambilan keputusan di tingkat konsumen, integrasi media, dan komunikasi di antara stakeholders, semuanya merupakan aspek-aspek yang harus ditingkatkan untuk mengelola komunikasi dalam era digital (Mulhern, 2009).

Berdasarkan bentuk promotion mix yang dilakukan oleh Kompepar Giriharja, dapat dilihat bahwa tidak semua elemen digunakan dalam agenda promosi desa wisata Jelekong. Dari keseluruhan bentuk promosi yang dilakukan Kompepar Giriharja, prioritas utama promosi dilakukan melalui event dan public relations. Kompepar Giriharja aktif dalam event, baik yang diselenggarakan Kompepar Giriharja maupun yang digelar pihak lain. Beberapa diantara event yang digelar tersebut, terdapat yang berbentuk event marketing. Event marketing biasanya dimaksudkan untuk mempromosikan peluncuran produk baru atau melancarkan kampanye produk tahunan. Harapan pelaksanaan event marketing ialah bertemu konsumen dan pelanggan dalam jumlah besar. Salah satu contoh pelaksanaan event marketing oleh Kompepar Giriharja ialah Launching sepuluh desa wisata di Kab. Bandung. Pada acara ini, harapan tersebut tercapai. 
Tabel 1. Media dan Promotion Mix Desa Wisata Jelekong

\begin{tabular}{ccccc}
\hline \multicolumn{2}{c}{ Tidak Bermedia } & \multicolumn{2}{c}{ Melalui Media } \\
\hline Jenis Media & Komunikasi tatap muka & Televisi & Surat Kabar & Internet Wayang golek dan Lukisan \\
Promotion Mix & $\begin{array}{c}\text { Public Relations } \\
\text { Personal Selling }\end{array}$ & Publikasi & Website & Pameran \\
Event & Merchandise
\end{tabular}

Sumber: olahan peneliti

Selain itu, pengurus Kompepar Giriharja aktif dalam membangun komunikasi dengan pihak eksternal melalui aktivitas public relations-nya, seperti kalangan pejabat pemerintahan maupun pihak swasta. Hal ini digunakan untuk mempermudah dalam akses penerimaan bantuan maupun sebagai peluang menjadikan Jelekong sebagai prioritas pembangunan wisata. Dalam menjalankan promosinya, pihak Kompepar Giriharja lebih menerapkan sistem "jemput bola" dengan mendatangi pihak-pihak untuk diajak bekerja sama.

Apabila ditinjau dari tujuan komunikasi pemasaran desa wisata Jelekong, yaitu tahap pembentukan awareness, strategi komunikasi yang dilakukan adalah perubahan pengetahuan (knowledge). Pada tahap ini, penggunaan media yang paling sesuai ialah media massa yang dapat menjangkau audiens dalam jumlah besar. Salah satu bentuk promosi menggunakan media ini adalah iklan. Pada kenyataannya di lapangan, bentuk promosi ini belum digunakan oleh Kompepar Giriharja. Hal ini disebabkan biaya pemasangan iklan yang besar, sementara anggaran masih terbatas. Bahkan dana yang ada diprioritaskan untuk pemenuhan sarana prasarana penunjang desa Jelekong sebagai desa seni dan budaya.

Promosi melalui internet yang mulai dilakukan oleh Kompepar Giriharja melalui pembuatan website giriharja-jelekong.com merupakan langkah yang tepat. Media ini memiliki keunggulan dibanding media lainnya, seperti menghilangkan jarak (geografis), biaya yang relatif murah, memungkinkan terjadinya komunikasi yang interaktif, hingga volume transfer informasi yang jauh lebih besar. Informasi yang disampaikan mengenai desa wisata Jelekong dapat lebih lengkap dan dipercaya karena disampaikan langsung dari pengurus Kompepar Giriharja. Sifatnya yang interaktif tersebut dapat memudahkan para pengunjung website untuk memperoleh informasi lebih lanjut pada pengurus Kompepar Giriharja. Sedangkan hal ini pun menguntungkan bagi pengurus Kompepar Giriharja untuk mengetahui feedback dari pengunjung website tersebut. Terlebih lagi target pengunjung desa wisata Jelekong adalah masyarakat luas, tidak dibatasi, sehingga penggunaan media ini dapat memaksimalkan upaya penyampaian informasi pada masyarakat. Saat ini kegiatan pariwisata banyak dipromosikan melalui media sosial seperti facebook dan twitter, selain promosi melalui brosur atau media cetak lain yang dapat disimpan di setiap hotel atau tempat-tempat sarana pendukung wisata lainnya, sehingga berbagai aktivitas di desa wisata dapat tersampaikan secara lebih luas (Mulhern, 2009).

Dari seluruh strategi promosi efektif yang ada, Kompepar Giriharja belum memperhatikan elemen terakhir, yakni mengintegrasikan bauran promosi (Integrated Marketing Communication atau IMC). Padahal elemen terakhir ini termasuk salah satu yang penting dalam agenda promosi. IMC akan memungkinkan target sasaran menerima pesan yang konsisten, terintegrasi, dan simultan. Seperti dikemukakan oleh Wise (2006) komunikasi pemasaran adalah sebagai strategi, teknik, dan semua aktivitas yang terkait dengan keinginan untuk menyampaikan pesan pemasaran yang diinginkan supaya dapat sampai kepada target pasar yang diinginkan terutama melalui berbagai media. IMC melibatkan gabungan berbagai teknik dan media komunikasi untuk meningkatkan pengetahuan dan pemahaman konsumen akan produk atau jasa yang 
dipromosikan (Keller, 2009). Penelitian lainnya yang dilakukan oleh Esposito (2013) membuktikan bahwa pada pimpinan perusahaan-perusahaan skala kecil dan menengah di Italia cenderung mulai menerapkan IMC sebagai strategi dalam merebut peluang pasar.

Penelitian ini pun akan menjelaskan hambatan yang dihadapi Kompepar dalam menjalankan strategi promosi. Hasil penelitian menunjukkan bahwa terdapat beberapa hambatan dalam pelaksanaan strategi promosi desa wisata Jelekong, baik yang bersifat teknis maupun non teknis. Umumnya pelaksanaan promosi terhambat karena beberapa hal bersifat non teknis dan berasal dari sumber komunikasi, seperti sumber anggaran promosi, sarana prasarana penunjang lokasi wisata, dukungan pelaku seni, hingga sumber daya manusianya.

Beberapa hambatan tersebut memang berasal dari pihak sumber penyampai pesan promosi dalam proses komunikasi ini, yaitu Kompepar Giriharja. Terutama hambatan berupa kurangnya SDM yang memiliki kapabilitas dalam bidang promosi turut menyebabkan perumusan tujuan serta pesan promosi yang kurang jelas. Padahal dalam hal negosiasi dan lobi, pengurus Kompepar Giriharja, terutama ketua telah memiliki kemampuan ini. Sesuai dengan pengakuan langsung ketua Kompepar Giriharja, Irwansyah, proses komunikasi dengan pihak pengambil kebijakan (pemerintahan maupun swasta), Kompepar Giriharja tidak mengalami kendala. Karena itulah, berbagai hambatan lain yang muncul, terutama dalam kesulitan dana dapat cukup diatasi melalui channeling yang dibangun para pengurus Kompepar Giriharja. Tujuan utama channeling ini adalah mencari celah dana bantuan untuk pengelolaan pariwisata Jelekong.

\section{KESIMPULAN}

Berdasarkan uraian yang telah disampaikan sebelumnya, diperoleh simpulan dari hasil penelitian. Kompepar Giriharja belum merumuskan strategi promosi secara komprehensif dan terintegrasi. Meskipun begitu, Kompepar Giriharja tetap menjalankan aktivitas promosi. Promosi yang dilaksanakan Kompepar Giriharja memiliki beberapa tujuan yang hendak dicapai, antara lain membangun awareness, meningkatkan knowledge, dan mengingatkan masyarakat mengenai desa wisata Jelekong beserta potensi wisatanya terutama seni dan budayanya, yaitu padepokan wayang golek dan sentra lukisan.
Tujuan kunjungan ke desa wisata Jelekong beragam, mulai dari wisata belanja, keperluan studi/ penelitian, studi banding, hingga belajar gamelan. Apabila diidentifikasi berdasarkan pengunjung yang datang hingga saat ini, audiens sasaran desa wisata Jelekong antara lain pelajar dan mahasiswa, tamu pemerintahan dan kenegaraan, instansi/perusahaan, media, dan umum. Sumber anggaran promosi yang pasti belum dimiliki Kompepar Giriharja. Beberapa sumber anggaran diperoleh melalui kerjasama dengan pihak Pemkab, Pemprov, maupun swasta. Berbagai dana bantuan, baik dari pemerintah maupun swasta umumnya masih diprioritaskan untuk pemenuhan sarana prasarana.

Aktivitas promosi yang belum tersusun menjadi program kerja Kompepar Giriharja menyebabkan aspek rancangan pesan belum terlalu diperhatikan. Isi pesan promosi umumnya masih berupa ide moral yang berisi penyampaian informasi mengenai desa wisata Jelekong. Sumber pesan tidak hanya pengurus Kompepar Giriharja saja, tak jarang tokoh pedalangan Giriharja, Jelekong pun secara tidak langsung, turut melakukan aktivitas penyampaian informasi mengenai desa wisata Jelekong.

Dalam menyebarkan pesan promosi, Kompepar Giriharja menggunakan berbagai media. Secara garis besar, media tersebut terbagi menjadi dua, yaitu saluran komunikasi tidak bermedia dan saluran komunikasi melalui media. Saluran komunikasi tidak bermedia yang digunakan ialah komunikasi tatap muka dan word of mouth. Sementara itu, saluran komunikasi melalui media yang digunakan antara lain televisi, surat kabar, dan internet. Selain itu, ikon Jelekong yang dikenal, wayang golek dan lukisan seringkali menjadi media dalam penyampaian pesan promosi. Melalui media-media tersebut, Kompepar Giriharja melaksanakan bauran promosi. Beberapa bentuk bauran promosi yang dijalankan Kompepar Giriharja, antara lain public relations, personal selling, event, eksibisi, merchandise, publikasi, dan website internet. Sarana promosi lain yang secara tidak langsung terjadi ialah word of mouth. Dari keseluruhan bentuk promosi yang dilakukan Kompepar Giriharja, prioritas utama promosi dilakukan melalui event dan public relations.

Umpan balik yang diperoleh Kompepar Giriharja berasal dari audiens sasaran atas aktivitas promosi, yakni calon pengunjung, serta para pelaku seni setempat. Aktivitas promosi tertentu cukup membuat jumlah kunjungan meningkat. Sementara itu, umpan 
balik dari pelaku seni Jelekong, terdapat sebagian orang pengrajin, khususnya pengrajin lukisan yang masih cenderung negatif dan kurang antusias dengan pembinaan yang dilakukan oleh Kompepar Giriharja. Namun tak sedikit pula jumlah pengrajin yang antusias dalam mengikuti berbagai program pembinaan yang dijembatani oleh Kompepar Giriharja.

Penelitian selanjutnya akan menarik untuk membahas mengenai aspek komunikasi dalam dualisme kepengurusan Kompepar di desa wisata Jelekong, yaitu Kompepar Giriharja dan Kompepar Gentong. Selain itu, dibutuhkan penyesuaian dalam komunikasi selama proses wawancara mendalam berlangsung. Terbatasnya pemahaman pengurus Kompepar Giriharja mengenai komunikasi pemasaran dan promosi menyebabkan perlu dilakukan penyesuaian dengan menyederhanakan istilah-istilah komunikasi pemasaran dan promosi. Selain itu, lingkungan penelitian masih bernuansa pedesaan dengan karakteristik sosial budaya yang khas, diperlukan adaptasi dengan budaya setempat.

\section{DAFTAR PUSTAKA}

Chandra, Satish dan Menezes, Dennis. 2001. Applications of Multivariate Analysis in International Tourism Research: The Marketing Strategy Perspective of NTOs. Journal of Economic and Social Research, 3(1): 77-98.

Dharmawan, Adi I Made., Sarjana, I Made., dan Yudhari, I Dewa A. S. 2014. Strategi Pengembangan Desa Wisata Di Desa Belimbing Kecamatan Pupuan Kabupaten Tabanan. E-Jurnal Agribisnis dan Agrowisata, 3(1).

Djayawangi, Hilman. 2013. Strategi Pemasaran Pariwisata di Jawa Barat Sebagai Upaya Meningkatkan Ekonomi Masyarakat, [Online]. Tersedia: www.disparbud.jabarprov.go.id/ applications/frontend/index.php?mod=news\&act =showdetail\&id=1692 [11 Oktober 2013].

Dombrowicz, Maria. 2013. Chrystkowo-A Thematic Tourist Village, is A New Offer for Tourism. Journal of Health Sciences, 3(15): 297-301.

Esposito, Annamaria. 2013. Insights about Integrated Marketing Communication in Small-and MediumSized Italian Enterprises. Business Systems Review, 2(1): 80-98.
Keller, Kevin Lane. 2009. Building Strong Brands in A Modern Marketing Communications Environment. Journal of Marketing Communications, 15(2-3).

Kotler, Philip \& Gary Armstrong. 2008. PrinsipPrinsip Pemasaran. Terjemahan Bob Sabran dari Principles of Marketing. Jakarta: Erlangga.

Litvin, Stephen W., Goldsmith, Ronald E., \& Pan, Big. 2008. Electronic Word of Mouth in Hospitality and Tourism Management. Tourism Management, 29(3): 458-468.

Lubis, Zulkarenain \& Osman, Abdullah. 2014. Indonesian Tourism Sector: A Potential Sector That Has Not Been Optimized. Australian Journal of Basic and Applied Sciences, 8(23): 286-290.

Mahmoudi, Beytola., Haghsetan, Amin., \& Maleki, Raheleh. 2011. Investigation of Obstacles and Strategies of Rural Tourism Development Using SWOT Matrix. Journal of Sustainable Development, 4(2): 136 - 141.

Marcomm Wise, S. 2006. Performance Consequences of Brand Equity Management Evidence from Organizations in The Value Chain. Journal of Product and Brand Management, 12(4): 220236.

Mihart, Camelia. 2012. Marketing Communication on Consumer Behaviour: Effects on Consumer Decision - Making Process. International Journal of Marketing Studies, 4(2).

Mulhern, Frank. 2009. Integrated Marketing Communications: from Media Channels to Digital Connectivity. Journal of Marketing Communications, 15(2-3).

Rehman, Shakeel U1. \& Ibrahim, M Syed. 2011. Integrated Marketing Communication and Promotion. International Refereed Research Journal, II(4).

Soebagyo. 2012. Strategi Pengembangan Pariwisata di Indonesia. Jurnal Liquidity, 1(2): 153-158.

Sung, Toh Pei, et al. 2012. Developing and Promoting a Highland Community Livelihood for Sustainable Tourism: The case of $\mathrm{Kg}$. Bundutuhan, Ranau, Sabah. Malaysia Journal of Society and Space, 8(5): $94-99$.

Suyanti, Dewi Winarni. 2013. Potensi Desa Melalui Pariwisata Pedesaan. Jurnal Ekonomi dan Bisnis, 12(1): 33-36. 